\title{
Prevention of Surgical Site Infection by Gentamicin- Impregnated Collagen Sponge (Collashield® Double Action) in Patients Who Underwent Abdominal Surgery
}

Jin Won Lee

Chuncheon Sacred Heart Hospital

Wan Joo Chun

Kangwon National University School of Medicine

Hae Sung Kim ( $\boldsymbol{D}$ biogra@hallym.or.kr)

Chuncheon Sacred Heart Hospital

\section{Research}

Keywords: Surgical Site Infection(SSI), Abdominal Surgery, Gentamicin-Impregnated

Posted Date: March 27th, 2020

DOI: https://doi.org/10.21203/rs.3.rs-18996/v1

License: (c) (1) This work is licensed under a Creative Commons Attribution 4.0 International License.

Read Full License 


\section{Abstract}

Background: The aim of this study was to evaluate the efficacy of the gentamicin-impregnated collagen sponge (GCS) in preventing SSI after abdominal surgeries.

Methods: We conducted a retrospective study to evaluate the effect of GCS in preventing postoperative surgical site infection (SSI) in patients who underwent abdominal surgeries. 194 patients (111 male and 83 female; mean age, 62 years; range, 20-96 years) who underwent abdominal surgery between January 2017 and December 2018 in Chuncheon Sacred Heart Hospital were included in this study. The primary endpoint was the development of any SSI within 1 month postoperatively.

Results: Of 194 patients studied, 30(20.1\%, control group) and 6(13.3\%, sponge group) in each group developed a SSI. However, subgroup analysis in patients with contaminated and dirty wound showed that SSI was occurred more frequently in the control group (15 of 36 [41.7\%]) than in the sponge group (3 of $22[13.6 \%])(P=0.04)$. Our data suggest that postoperative SSI can be reduced by using GCS in in the group of patients with contaminated and dirty wound classes.

Conclusions: The SSI rate after abdominal surgeries was reduced in the group of patients with contaminated and dirty wound classes, by using GCS. We should consider to use GCS in patients with these type of wounds.

Key words: Surgical Site Infection(SSI), Abdominal Surgery, Gentamicin-Impregnated

\section{Background}

Surgical site infection (SSI) is a common complication after abdominal surgery. SSI rates have been reported up to $20 \%$ in several studies [1-3]. Prophylactic methods include systemic antibiotic use, control of the operating room environment, and improvements of surgical techniques [4-6]. Appropriate wound management is important in surgical patients because wound problems are associated with profound morbidity, impaired quality of life and significant economic costs. Also SSI is associated with length of hospital stay and increased hospital costs. As a result, the prevention of SSI is important to get a great benefit in terms of individual health and economic issues.

Therefore, surgeon should actively involve in wound care to minimize the SSI. Systematic care, including correction of medical co-morbidities, improvement of nutritional status, or surgical debridement of infected wound should be performed in accordance with proper use of antimicrobial agents to facilitate optimal wound healing [7-9].

A gentamicin-impregnated collagen sponge (GCS) has been developed to prevent SSI. This re-absorbable material is designed to be implanted before closure of the wound in many types of surgeries including abdominal, dental, cardiac, breast or orthopedic surgeries [2, 3, 5, 10-14]. The GCS is composed of highly purified type I collagen obtained from bovine tendon, which acts as a vehicle for the antimicrobial 
gentamicin. So it maintains high local concentrations of gentamicin, so that minimize postoperative bacterial growth, preventing SSI.

Some studies have demonstrated the effectiveness of the GCS in abdominal surgery patients.

Rutten et al. [2] concluded that GCS was effective to reduce postoperative wound infection rates to levels lower than those currently achieved with systemic antibiotics alone. However, one meta-analysis by Nelson et al. [1] showed conflicting results probably due to varying methodologies, study populations, small sample size, and lack of randomized trial. Furthermore, most of studies were limited in colorectal surgery.

Therefore, the objective of this study was to determine whether GCS reduces SSI after abdominal surgeries including gastrointestinal, hepato-biliary, pancreatic and biliary surgeries. We compared postoperative SSI rates in 194 patients who underwent abdominal surgery with (Sponge group, $n=49$ ) or without (Control group, $n=145$ ) the GCS, retrospectively.

\section{Methods}

\section{Patients}

Between January 2017 and December 2018, 194 patients who underwent abdominal surgery with (Sponge group, $n=49$ ) or without (Control group, $n=145$ ) the GCS, were selected respectively. All of the 194 patients enrolled in the present study received a complete evaluation included physical examination, blood tests, chest and electrocardiography prior to surgery. Patients with either elective or emergency operation were included. Patients who underwent laparoscopic surgeries or leaving the wound open during first few days after surgery (delayed wound closure), were excluded. Types of surgical wound were classified by the American College of Surgeons considering the following categories: (1) clean wounds; (2) contaminated clean wounds; (3) contaminated wounds; and 94) dirty wounds [15, 16].

Approval for this study was obtained from our Institutional Review Broad.

\section{Operative procedure}

During the study period, Collashield $®$ Double Action (BNC KOREA, Taegu, Korea) was to be used randomly according to surgeon's preference. Each sponge ( 5 by $5 \mathrm{~cm}$ ) contained $2.8 \mathrm{mg} / \mathrm{cm}^{2}$ of bovine collagen and $2.0 \mathrm{mg} / \mathrm{cm}^{2}$ of gentamicin sulfate. We inserted one sponge, which was cut into strips according to the length of wound, anteriorly to the fascia immediately before closure of the wound.

\section{Diagnosis of SSI}

Patients with SSI usually present the signs and symptoms such as wound pain, redness or swelling of the wound, or dehiscence with/without drainage of pus. If there were clear evidences of SSI, we performed 
wound exploration and swab culture for diagnosis. If the patients showed no specific signs or symptoms, we considered computed tomography (CT) for accurate diagnosis for deep or organ space SSI.

\section{End points}

The primary endpoint was SSI including abnormal fluid collection or abscess formation in subcutaneous space or deeper spaces within 1 month after surgery. We assessed the presence of SSI by reviewing electronic medical records of hospital data and outpatient department follow-up.

\section{Statistical analysis}

Continuous data were expressed as the mean \pm standard deviation. Student's $t$ test and Fisher's exact probability test were used for the analysis each of continuous and categorical data. Data analysis was performed using SPSS software (Version 12.0; SPSS, Chicago, II1). P Values $<0.05$ were considered statistically significant.

\section{Results}

Baseline characteristics and overall SSI rates were summarized in Table 1. There were no significant differences between two groups in terms of various factors except for type of wound. Sponge group was consisted relatively large proportion of contaminated and dirty wound rather than control group, representing surgeons intended to use the GCS more frequently in patients with contaminated and dirty wound. However, the overall SSI rates were not different significantly between two groups. Of 194 patients studied, $30(20.1 \%$, control group) and $6(13.3 \%$, sponge group) in each group developed SSIs. In univariate analysis using Fisher's exact probability test showed that only the type of wound was associated with SSI development significantly $(P=0.025)$. SSI was occurred more frequently in patients with co-morbidities (hypertension, DM, COPD, cardiac disease, renal disease or liver cirrhosis) but, the results were not reached to the statistical significance. Also the use of GCS was not associated with SSI development significantly $(P=0.384)$ (Table 2.). However, subgroup analysis in patients with contaminated and dirty wound showed that SSI was occurred more frequently in the control group (15 of $36[41.7 \%])$ than in the sponge group (3 of 22 [13.6\%]) $(P=0.04)$ (Table 3). Both depth of SSI and type of complication according to Clavian-Dindo classification were not different significantly between two groups (Table 4). 
Table 1

Baseline characteristics and overall SSI rates

\begin{tabular}{|c|c|c|c|}
\hline & $\begin{array}{l}\text { Control group(\%) } \\
(n=149)\end{array}$ & $\begin{array}{l}\text { Sponge group(\%) } \\
(n=45)\end{array}$ & P value \\
\hline $\begin{array}{l}\text { Gender } \\
\text { Male } \\
\text { Female }\end{array}$ & $\begin{array}{l}87(58.4) \\
62(41.6)\end{array}$ & $\begin{array}{l}24(53.3) \\
21(46.7)\end{array}$ & 0.607 \\
\hline Age & $63.41 \pm 17.66$ & $61.42 \pm 18.20$ & 0.551 \\
\hline $\begin{array}{l}<60 \\
\geq 60\end{array}$ & $\begin{array}{l}55(36.9) \\
94(63.1)\end{array}$ & $\begin{array}{l}19(42.2) \\
26(57.8)\end{array}$ & 0.600 \\
\hline $\mathrm{BMI}\left(\mathrm{kg} / \mathrm{m}^{2}\right)$ & $22.27 \pm 3.52$ & $23.25 \pm 2.83$ & 0.114 \\
\hline $\begin{array}{l}<25 \\
\geq 25\end{array}$ & $\begin{array}{l}116(77.9) \\
33(22.1)\end{array}$ & $\begin{array}{l}32(71.1) \\
13(28.9)\end{array}$ & 0.424 \\
\hline Hospital stay(days) & $18.43 \pm 20.89$ & $19.91 \pm 14.47$ & 0.665 \\
\hline Operation time(min) & $117.31 \pm 78.55$ & $106.22 \pm 73.10$ & 0.400 \\
\hline $\begin{array}{l}\text { ASA score } \\
1 \\
2 \\
3 \\
4 \\
5\end{array}$ & $\begin{array}{l}7(4.7) \\
72(48.3) \\
56(37.6) \\
12(8.1) \\
2(1.3)\end{array}$ & $\begin{array}{l}4(8.9) \\
20(44.4) \\
17(37.8) \\
3(6.7) \\
1(2.2)\end{array}$ & 0.860 \\
\hline $\begin{array}{l}\text { Elective } \\
\text { Emergency }\end{array}$ & $\begin{array}{l}54(36.2) \\
95(63.8)\end{array}$ & $\begin{array}{l}12(26.7) \\
33(73.3)\end{array}$ & 0.283 \\
\hline $\begin{array}{l}\text { HTN } \\
\text { No } \\
\text { Yes }\end{array}$ & $\begin{array}{l}95(65.8) \\
51(34.2)\end{array}$ & $\begin{array}{l}30(66.7) \\
15(33.3)\end{array}$ & 1.000 \\
\hline $\begin{array}{l}\text { DM } \\
\text { No } \\
\text { Yes }\end{array}$ & $\begin{array}{l}124(83.2) \\
25(16.8)\end{array}$ & $\begin{array}{l}38(84.4) \\
7(15.6)\end{array}$ & 1.000 \\
\hline $\begin{array}{l}\text { COPD } \\
\text { No } \\
\text { Yes }\end{array}$ & $\begin{array}{l}141(94.6) \\
8(5.4)\end{array}$ & $\begin{array}{l}44(97.8) \\
1(2.2)\end{array}$ & 0.468 \\
\hline $\begin{array}{l}\text { Cardia disease } \\
\text { No } \\
\text { Yes }\end{array}$ & $\begin{array}{l}130(87.2) \\
19(12.8)\end{array}$ & $\begin{array}{l}39(86.7) \\
6(13.3)\end{array}$ & 1.000 \\
\hline
\end{tabular}

BMI, body mass index; ASA, American Society of Anesthesiologists; HTN, hypertension; DM, diabetes mellitus; COPD, chronic obstructive pulmonary disease

*The results of Pearson chi-squire test for risk factors. 


\begin{tabular}{|c|c|c|c|}
\hline & $\begin{array}{l}\text { Control group(\%) } \\
(n=149)\end{array}$ & $\begin{array}{l}\text { Sponge group(\%) } \\
(n=45)\end{array}$ & P value $^{*}$ \\
\hline $\begin{array}{l}\text { Renal disease } \\
\text { No } \\
\text { Yes }\end{array}$ & $\begin{array}{l}144(96.6) \\
5(3.4)\end{array}$ & $\begin{array}{l}45(100) \\
0(0)\end{array}$ & 0.346 \\
\hline $\begin{array}{l}\text { Liver Cirrhosis } \\
\text { No } \\
\text { Yes }\end{array}$ & $\begin{array}{l}145(97.3) \\
4(2.7)\end{array}$ & $\begin{array}{l}44(97.8) \\
1(2.2)\end{array}$ & 1.000 \\
\hline $\begin{array}{l}\text { Previous Laparotomy } \\
\text { No } \\
\text { Yes }\end{array}$ & $\begin{array}{l}105(70.5) \\
44(29.5)\end{array}$ & $\begin{array}{l}35(77.8) \\
10(22.2)\end{array}$ & 0.353 \\
\hline $\begin{array}{l}\text { Previous Chemotherapy } \\
\text { No } \\
\text { Yes }\end{array}$ & $\begin{array}{l}140(94.0) \\
9(6.0)\end{array}$ & $\begin{array}{l}43(95.6) \\
2(4.4)\end{array}$ & 0.743 \\
\hline $\begin{array}{l}\text { Previous Radiation } \\
\text { No } \\
\text { Yes }\end{array}$ & $\begin{array}{l}147(98.7) \\
2(1.3)\end{array}$ & $\begin{array}{l}45(100) \\
0(0)\end{array}$ & 1.000 \\
\hline $\begin{array}{l}\text { Type of wound } \\
\text { Clean } \\
\text { Clean-contaminated } \\
\text { Contaminated } \\
\text { Dirty }\end{array}$ & $\begin{array}{l}12(8.1) \\
101(61.8) \\
28(18.8) \\
8(5.4)\end{array}$ & $\begin{array}{l}5(11.1) \\
18(40.0) \\
19(24.2) \\
3(5.7)\end{array}$ & 0.006 \\
\hline $\begin{array}{l}\text { Type of surgery } \\
\text { Appendectomy } \\
\text { Abdominal wall } \\
\text { Bile duct } \\
\text { Bladder } \\
\text { Gastric } \\
\text { Gallbladder } \\
\text { Hernia } \\
\text { Colorectal } \\
\text { Liver } \\
\text { Intraperitoneal mass } \\
\text { Pancreas } \\
\text { Small intestine } \\
\text { Spleen }\end{array}$ & $\begin{array}{l}8(5.4) \\
2(1.3) \\
5(3.4) \\
1(0.7) \\
26(17.4) \\
15(10.1) \\
3(2.0) \\
40(26.8) \\
3(2.0) \\
1(0.7) \\
5(3.4) \\
39(26.2) \\
1(0.7)\end{array}$ & $\begin{array}{l}1(2.2) \\
1(2.2) \\
0(0) \\
0(0) \\
15(33.3) \\
5(11.1) \\
1(2.2) \\
5(11.1) \\
0(0) \\
1(2.2) \\
0(0) \\
15(33.3) \\
1(2.2)\end{array}$ & 0.228 \\
\hline $\begin{array}{l}\text { Wound Infection } \\
\text { No } \\
\text { Yes }\end{array}$ & $\begin{array}{l}119(79.9) \\
30(20.1 \%)\end{array}$ & $\begin{array}{l}39(86.7) \\
6(13.3 \%)\end{array}$ & 0.384 \\
\hline \multicolumn{4}{|c|}{$\begin{array}{l}\text { BMI, body mass index; ASA, American Society of Anesthesiologists; HTN, hypertension; DM, diabete } \\
\text { mellitus; COPD, chronic obstructive pulmonary disease }\end{array}$} \\
\hline
\end{tabular}


Table 2

SSI rates according to the patients characteristics.

\begin{tabular}{|c|c|c|c|}
\hline & Infection(-) & Infection(+) & P value ${ }^{*}$ \\
\hline $\begin{array}{l}\text { Gender } \\
\text { Male } \\
\text { Female }\end{array}$ & $\begin{array}{l}87(78.4) \\
71(85.5)\end{array}$ & $\begin{array}{l}24(21.6) \\
12(14.5)\end{array}$ & 0.263 \\
\hline $\begin{array}{l}\text { Age } \\
<60 \\
\geq 60\end{array}$ & $\begin{array}{l}62(83.8) \\
96(80.0)\end{array}$ & $\begin{array}{l}12(16.2) \\
24(20.0)\end{array}$ & 0.572 \\
\hline $\begin{array}{l}\mathrm{BMl}\left(\mathrm{kg} / \mathrm{m}^{2}\right) \\
<25 \\
\geq 25\end{array}$ & $\begin{array}{l}124(83.8) \\
34(80.0)\end{array}$ & $\begin{array}{l}24(16.2) \\
12(20.0)\end{array}$ & 0.191 \\
\hline $\begin{array}{l}\text { ASA score } \\
1 \\
2 \\
3 \\
4 \\
5\end{array}$ & $\begin{array}{l}11(100) \\
77(83.7) \\
58(79.5) \\
10(66.7) \\
2(66.7)\end{array}$ & $\begin{array}{l}0(0) \\
15(16.3) \\
15(41.7) \\
5(33.3) \\
1(33.3)\end{array}$ & 0.227 \\
\hline $\begin{array}{l}\text { Elective } \\
\text { Emergency }\end{array}$ & $\begin{array}{l}58(87.9) \\
100(78.1)\end{array}$ & $\begin{array}{l}8(12.1) \\
28(21.9)\end{array}$ & 0.12 \\
\hline $\begin{array}{l}\text { HTN } \\
\text { No } \\
\text { Yes }\end{array}$ & $\begin{array}{l}107(83.6) \\
51(77.3)\end{array}$ & $\begin{array}{l}21(16.4) \\
15(22.7)\end{array}$ & 0.331 \\
\hline $\begin{array}{l}\text { DM } \\
\text { No } \\
\text { Yes }\end{array}$ & $\begin{array}{l}135(93.3) \\
23(71.9)\end{array}$ & $\begin{array}{l}27(16.7) \\
9(28.1)\end{array}$ & 0.139 \\
\hline $\begin{array}{l}\text { COPD } \\
\text { No } \\
\text { Yes }\end{array}$ & $\begin{array}{l}151(81.6) \\
7(77.8)\end{array}$ & $\begin{array}{l}34(18.4) \\
2(22.2)\end{array}$ & 0.674 \\
\hline $\begin{array}{l}\text { Cardiac disease } \\
\text { No } \\
\text { Yes }\end{array}$ & $\begin{array}{l}140(82.8) \\
18(72.0)\end{array}$ & $\begin{array}{l}29(17.2) \\
7(28.0)\end{array}$ & 0.267 \\
\hline $\begin{array}{l}\text { Renal disease } \\
\text { No } \\
\text { Yes }\end{array}$ & $\begin{array}{l}155(82.0) \\
3(60.0)\end{array}$ & $\begin{array}{l}34(18.0) \\
2(40.0)\end{array}$ & 0.232 \\
\hline $\begin{array}{l}\text { Liver Cirrhosis } \\
\text { No } \\
\text { Yes }\end{array}$ & $\begin{array}{l}154(81.5) \\
4(80.0)\end{array}$ & $\begin{array}{l}35(18.5) \\
1(20.0)\end{array}$ & 1.000 \\
\hline
\end{tabular}

BMI, body mass index; ASA, American Society of Anesthesiologists; HTN, hypertension; DM, diabetes mellitus; COPD, chronic obstructive pulmonary disease

*The results of Pearson chi-squire test for risk factors. 


\begin{tabular}{|c|c|c|c|}
\hline & Infection(-) & Infection(+) & P value ${ }^{*}$ \\
\hline $\begin{array}{l}\text { Previous Laparotomy } \\
\text { No } \\
\text { Yes }\end{array}$ & $\begin{array}{l}113(80.7) \\
45(83.3)\end{array}$ & $\begin{array}{l}27(19.3) \\
9(16.7)\end{array}$ & 0.690 \\
\hline $\begin{array}{l}\text { Previous Chemotherapy } \\
\text { No } \\
\text { Yes }\end{array}$ & $\begin{array}{l}147(80.3) \\
11(100)\end{array}$ & $\begin{array}{l}36(19.7) \\
0(0)\end{array}$ & 0.131 \\
\hline $\begin{array}{l}\text { Previous Radiation } \\
\text { No } \\
\text { Yes }\end{array}$ & $\begin{array}{l}156(81.3) \\
2(100)\end{array}$ & $\begin{array}{l}36(18.7) \\
0(0)\end{array}$ & 1.000 \\
\hline $\begin{array}{l}\text { Type of wound } \\
\text { Clean } \\
\text { Clean-contaminated } \\
\text { Contaminated } \\
\text { Dirty }\end{array}$ & $\begin{array}{l}16(94.1) \\
102(85.7) \\
32(68.1) \\
8(72.7)\end{array}$ & $\begin{array}{l}1(5.9) \\
17(14.3) \\
15(31.9) \\
11(27.3)\end{array}$ & 0.025 \\
\hline $\begin{array}{l}\text { Control group } \\
\text { Sponge group }\end{array}$ & $\begin{array}{l}119(79.9) \\
39(86.7)\end{array}$ & $\begin{array}{l}30(20.1) \\
6(13.3)\end{array}$ & 0.384 \\
\hline \multicolumn{4}{|c|}{$\begin{array}{l}\text { BMI, body mass index; ASA, American Society of Anesthesiologists; HTN, hypertension; DM, diabetes } \\
\text { mellitus; COPD, chronic obstructive pulmonary disease }\end{array}$} \\
\hline
\end{tabular}


Table 3

Subgroup analysis in patients with contaminated and dirty wound classes

\begin{tabular}{|c|c|c|c|}
\hline & $\begin{array}{l}\text { Infection(-)(\%) } \\
(n=40)\end{array}$ & $\begin{array}{l}\text { Infection(+)(\%) } \\
(n=18)\end{array}$ & P value ${ }^{*}$ \\
\hline $\begin{array}{l}\text { Gender } \\
\text { Male } \\
\text { Female }\end{array}$ & $\begin{array}{l}22(62.9) \\
18(78.3)\end{array}$ & $\begin{array}{l}13(37.1) \\
5(21.7)\end{array}$ & 0.257 \\
\hline $\begin{array}{l}\text { Age } \\
<60 \\
\geq 60\end{array}$ & $\begin{array}{l}18(78.3) \\
22(62.9)\end{array}$ & $\begin{array}{l}5(21.7) \\
13(37.1)\end{array}$ & 0.257 \\
\hline $\begin{array}{l}\mathrm{BMI}\left(\mathrm{kg} / \mathrm{m}^{2}\right) \\
<25 \\
\geq 25\end{array}$ & $\begin{array}{l}34(73.9) \\
6(50.0)\end{array}$ & $\begin{array}{l}12(26.1) \\
6(50.0)\end{array}$ & 0.161 \\
\hline $\begin{array}{l}\text { ASA score } \\
1 \\
2 \\
3 \\
4 \\
5\end{array}$ & $\begin{array}{l}5(100) \\
17(73.9) \\
13(59.1) \\
4(57.1) \\
1(100)\end{array}$ & $\begin{array}{l}0(0) \\
6(26.1) \\
9(40.9) \\
3(42.9) \\
0(0)\end{array}$ & 0.377 \\
\hline $\begin{array}{l}\text { Elective } \\
\text { Emergency }\end{array}$ & $\begin{array}{l}0(0) \\
40(69.0)\end{array}$ & $\begin{array}{l}0(0) \\
18(31.0)\end{array}$ & - \\
\hline $\begin{array}{l}\text { HTN } \\
\text { No } \\
\text { Yes }\end{array}$ & $\begin{array}{l}30(73.2) \\
10(58.8)\end{array}$ & $\begin{array}{l}11(26.8) \\
7(41.2)\end{array}$ & 0.354 \\
\hline $\begin{array}{l}\text { DM } \\
\text { No } \\
\text { Yes }\end{array}$ & $\begin{array}{l}35(70.0) \\
5(62.5)\end{array}$ & $\begin{array}{l}15(30.0) \\
3(37.5)\end{array}$ & 0.694 \\
\hline $\begin{array}{l}\text { COPD } \\
\text { No } \\
\text { Yes }\end{array}$ & $\begin{array}{l}39(68.4) \\
1(100)\end{array}$ & $\begin{array}{l}18(31.6) \\
0(0)\end{array}$ & 1.000 \\
\hline $\begin{array}{l}\text { Cardiac disease } \\
\text { No } \\
\text { Yes }\end{array}$ & $\begin{array}{l}38(73.1) \\
2(33.3)\end{array}$ & $\begin{array}{l}14(26.9) \\
4(66.7)\end{array}$ & 0.068 \\
\hline $\begin{array}{l}\text { Renal disease } \\
\text { No } \\
\text { Yes }\end{array}$ & $\begin{array}{l}40(69.0) \\
0(0)\end{array}$ & $\begin{array}{l}18(31.0) \\
0(0)\end{array}$ & - \\
\hline $\begin{array}{l}\text { Liver Cirrhosis } \\
\text { No } \\
\text { Yes }\end{array}$ & $\begin{array}{l}40(69.0) \\
0(0)\end{array}$ & $\begin{array}{l}18(31.0) \\
0(0)\end{array}$ & - \\
\hline
\end{tabular}

BMI, body mass index; ASA, American Society of Anesthesiologists; HTN, hypertension; DM, diabetes mellitus; COPD, chronic obstructive pulmonary disease

*The results of Pearson chi-squire test for risk factors. 


\begin{tabular}{|c|c|c|c|}
\hline & $\begin{array}{l}\text { Infection(-)(\%) } \\
(n=40)\end{array}$ & $\begin{array}{l}\text { Infection(+)(\%) } \\
(n=18)\end{array}$ & P value $^{*}$ \\
\hline $\begin{array}{l}\text { Previous Laparotomy } \\
\text { No } \\
\text { Yes }\end{array}$ & $\begin{array}{l}36(66.7) \\
4(100)\end{array}$ & $\begin{array}{l}18(33.3) \\
0(0)\end{array}$ & 0.300 \\
\hline $\begin{array}{l}\text { Previous Chemotherapy } \\
\text { No } \\
\text { Yes }\end{array}$ & $\begin{array}{l}40(69.0) \\
0(0)\end{array}$ & $\begin{array}{l}18(31.0) \\
0(0)\end{array}$ & - \\
\hline $\begin{array}{l}\text { Previous Radiation } \\
\text { No } \\
\text { Yes }\end{array}$ & $\begin{array}{l}40(69.0) \\
0(0)\end{array}$ & $\begin{array}{l}18(31.0) \\
0(0)\end{array}$ & - \\
\hline $\begin{array}{l}\text { Control group } \\
\text { Sponge group }\end{array}$ & $\begin{array}{l}21(58.3) \\
19(86.4)\end{array}$ & $\begin{array}{l}15(41.7) \\
3(13.6)\end{array}$ & 0.040 \\
\hline \multicolumn{4}{|c|}{$\begin{array}{l}\text { BMI, body mass index; ASA, American Society of Anesthesiologists; HTN, hypertension; DM, diabetes } \\
\text { mellitus; COPD, chronic obstructive pulmonary disease }\end{array}$} \\
\hline
\end{tabular}

Table 4

Type of SSI and complication according to CDC

\begin{tabular}{|c|c|c|c|}
\hline & $\begin{array}{l}\text { Control group (\%) } \\
(n=30)\end{array}$ & $\begin{array}{l}\text { Sponge group (\%) } \\
(n=6)\end{array}$ & P value ${ }^{*}$ \\
\hline $\begin{array}{l}\text { Depth of SSI } \\
\text { Superficial } \\
\text { Deep } \\
\text { Organ space }\end{array}$ & $\begin{array}{l}25(83.3) \\
3(10.0) \\
2(6.7)\end{array}$ & $\begin{array}{l}5(83.3) \\
1(16.7) \\
0(0)\end{array}$ & 0.753 \\
\hline $\begin{array}{l}\text { CDC } \\
\text { I } \\
\text { II } \\
\text { III }\end{array}$ & $\begin{array}{l}5(16.7) \\
23(76.7) \\
2(6.7)\end{array}$ & $\begin{array}{l}1(16.7) \\
5(83.3) \\
0(0)\end{array}$ & 0.744 \\
\hline \multicolumn{4}{|c|}{ CDC, Clavian-Dindo Classification } \\
\hline
\end{tabular}

\section{Discussions}

SSI is associated with quality of life, increased lengths of hospital stay, so that significant benefits is expected from the prevention of SSI. The GCS was developed to reduce SSI by providing high local gentamicin concentrations but no the high systemic concentrations associated with nephrotoxicity [17]. The GCS was first approved in Germany in 1985 and is currently used in over 60 countries [14]. In view of these results, our department of surgery started to use GCS in early 2017. 
However, there have been some controversies about the role of GCS. In previous study conducted on the use of GCS in reducing SSI, Musella et al.[18] examined its use in prosthetic repair of inguinal hernia and concluded that it was effective in reducing SSI. However, Anderson et al.[19], who examined the use of GCS in pilonidal sinus excision, concluded that GCS was not effective in reducing SSI. In our results, overall SSI rate for the sponge group was $13.3 \%$ ( 6 of 45 ), while SSI rate for control group was $20.1 \%$ (30 of 149); $P=0.384$. With these results, we aimed to be selective in the use of GCS and to identify the subgroup of patients who would benefit most from it in our study. As Liau et al.[20] demonstrated low SSI rates for clean and clean-contaminated wounds ( $0 \%$ and $1.1 \%$, respectively, from the period of 2005 to 2007), our results showed that SSI rate for these wounds were $5.9 \%$ and $14.3 \%$, respectively. Plus, Chia et al.[21] concluded that dirty-infected wounds have the most potential for benefiting from GCS on other wound classes. However, there were only 19 patients with dirty wound in our series, so we conducted subgroup analysis combining contaminated and dirty wound together. As shown in Table 3, SSI rate for contaminated and dirty wounds were $41.7 \%$ (15 of 36 ) in control group and $13.6 \%(3$ of 22 ) in sponge group, respectively; $P=0.04$. One study demonstrated that dirty wounds carry a risk of infection in up to $45 \%$, regardless of all measures taken to reduce the incidence of SSI, such as the improvements in surgical techniques and the use of perioperative systemic antibiotics [15].

The organisms most frequently found in SSI are the gram-negative anaerobes such as Escherichia coli, Klebsiella sp., Proteus $\mathrm{mb}$ and Pseudomonas aeruginosa, among others; therefore aminoglycosides should be included in the treatment regimens for the SSI [16, 22]. For gentamicin, a positive influence on anastomotic healing and the quality of collagen formation could be shown [23], whereas Bang et al.[24] reported GCS hampering epithelialization and neovascularization in a mouse model. Vaneerdeweg et al. [24] set up a rat model in which nearly all rats in the collagen group developed anastomotic breakdowns. However, there were no cases of wound disruption or incisional hernia in both groups during the study periods.

In our results, the length of hospital stay was not different between two group (18.43 \pm 20.89 versus $19.91 \pm 14.47 ; P=0.665)$. But Sponge group was consisted relatively large proportion of contaminated and dirty wound rather than control group that means sponge group is consisted with more severe patients compared to control group.

It has been well known that immediate closure of contaminated or dirty abdominal wounds at the time of surgery increases the risk of SSI. The most frequent method for preventing SSI consists in leaving the wound open and closing it within 3 to 5 days. However this make the patients feel severe pain during the wound dressing until wound is closed and it is associated with increased length of hospital stay. Therefore, the GCS is more comfortable and effective rather than delayed wound closure.

This study has several limits. First one is that this is retrospective study. Also the use of GCS was determined by surgeon's preferences. Finally, we used only 1 size of GCS in this study, however, previous study demonstrated that larger size of GCS is more effective related to the size of wound [21]. Randomized controlled trial using several sizes of GCS is needed in the future. 


\section{Conclusions}

In conclusion, our results demonstrate that the SSI rate after abdominal surgeries was reduced in the group of patients with contaminated and dirty wound classes, by using GCS. We should consider to use GCS in patients with these type of wounds.

\section{Abbreviations}

GCS

Gentamicin-impregnated Collagen Sponge

SSI

Surgical Site Infection

CT

Computed Tomography

DM

Diabetes Mellitus

COPD

Chronic Obstructive Pulmonary Disease

\section{Declarations}

\section{Acknowledgements}

Not applicable.

\section{Funding}

There was no funding for this study

\section{Authors' contributions}

JW carried out the conception and drafting the manuscript. HS carried out the acquisition of data, interpretation of data, drafting the manuscript and revising it. WJ participated in the design of the study and performed the statistical analysis. All authors have read and approved the final manuscript.

\section{Availability of data and materials}

The material supporting the conclusion of this study has been included in the manuscript.

\section{Competing interests}

No author has any conflict of interest of source of funding relevant to this study to declare. 
The institutional review board of Chuncheon Sacred Heart Hospital approved this study.

\section{Consent for publication}

Written informed consent was obtained from the patient himself.

\section{References}

1. Lv Y-F, Wang J, Dong F, Yang D-H. Meta-analysis of local gentamicin for prophylaxis of surgical site infections in colorectal surgery. Int J Colorectal Dis. 2016;31:393-402.

2. Rutten HJ, Nijhuis PH. Prevention of wound infection in elective colorectal surgery by local application of a gentamicin-containing collagen sponge. Eur J Surg Suppl. 1997;:31-5.

3. Bennett-Guerrero E, Pappas TN, Koltun WA, Fleshman JW, Lin M, Garg J, et al. Gentamicin-collagen sponge for infection prophylaxis in colorectal surgery. N Engl J Med. 2010;363:1038-49.

4. Birgand G, Radu C, Alkhoder S, Al Attar N, Raffoul R, Dilly M-P, et al. Does a gentamicin-impregnated collagen sponge reduce sternal wound infections in high-risk cardiac surgery patients? Interact Cardiovasc Thorac Surg. 2013;16:134-41.

5. Alberts VP, Minnee RC, Bemelman FJ, van Donselaar-van der Pant KAMI, Idu MM. Effect of gentamicin-containing collagen sponges on surgical site infection after hand-assisted laparoscopic donor nephrectomy. Surg Infect (Larchmt). 2013;14:451-4.

6. Effect of local gentamicin application on healing and wound infection in patients with modified radical mastectomy: a prospective randomized study. - PubMed - NCBI.

https://www.ncbi.nlm.nih.gov/pubmed/20926017. Accessed 15 May 2019.

7. Abdelrahman T, Newton H. Wound dressings: principles and practice. Surgery (Oxford). 2011;29:491-5.

8. Kramer SA. Effect of povidone-iodine on wound healing: A review. Journal of Vascular Nursing. 1999;17:17-23.

9. A K, D B, J W, Wc B. Effect of povidone iodine dermatologic ointment on wound healing. Am Surg. 1995;61:486-91.

10. Cho H, Jung H-D, Kim B-J, Kim C-H, Jung Y-S. Complication rates in patients using absorbable collagen sponges in third molar extraction sockets: a retrospective study. J Korean Assoc Oral Maxillofac Surg. 2015;41:26-9.

11. Joshi V, Vaja R, Richens D. Cost analysis of gentamicin-impregnated collagen sponges in preventing sternal wound infection post cardiac surgery. J Wound Care. 2016;25:22-5.

12. Nguyen AL, Pronk AA, Furnée EJB, Pronk A, Davids PHP, Smakman N. Local administration of gentamicin collagen sponge in surgical excision of sacrococcygeal pilonidal sinus disease: a systematic review and meta-analysis of the literature. Tech Coloproctol. 2016;20:91-100.

13. Haase O, Raue W, Böhm B, Neuss H, Scharfenberg M, Schwenk W. Subcutaneous gentamycin implant to reduce wound infections after loop-ileostomy closure: a randomized, double-blind, 
placebo-controlled trial. Dis Colon Rectum. 2005;48:2025-31.

14. Brehant O, Sabbagh C, Lehert P, Dhahri A, Rebibo L, Regimbeau JM. The gentamicin-collagen sponge for surgical site infection prophylaxis in colorectal surgery: a prospective case-matched study of 606 cases. Int J Colorectal Dis. 2013;28:119-25.

15. Guzmán Valdivia Gomez G, Guerrero TS, Lluck MC, Delgado FJ. Effectiveness of collagen-gentamicin implant for treatment of "dirty" abdominal wounds. World J Surg. 1999;23:123-6; discussion 126127.

16. Berard F, Gandon J. POSTOPERATIVE WOUND INFECTIONS: THE INFLUENCE OF ULTRAVIOLET IRRADIATION OF THE OPERATING ROOM AND OF VARIOUS OTHER FACTORS. Ann Surg. 1964;160 Suppl 2:1-192.

17. Murray BW, Huerta S, Dineen S, Anthony T. Surgical site infection in colorectal surgery: a review of the nonpharmacologic tools of prevention. J Am Coll Surg. 2010;211:812-22.

18. Musella M, Guido A, Musella S. Collagen tampons as aminoglycoside carriers to reduce postoperative infection rate in prosthetic repair of groin hernias. Eur J Surg. 2001;167:130-2.

19. Andersson RE, Lukas G, Skullman S, Hugander A. Local administration of antibiotics by gentamicincollagen sponge does not improve wound healing or reduce recurrence rate after pilonidal excision with primary suture: a prospective randomized controlled trial. World J Surg. 2010;34:3042-8.

20. Liau K-H, Aung K-T, Chua N, Ho C-K, Chan C-Y, Kow A, et al. Outcome of a strategy to reduce surgical site infection in a tertiary-care hospital. Surg Infect (Larchmt). 2010;11:151-9.

21. Chia CLK, Shelat VG, Low W, George S, Rao J. The use of Collatamp G, local gentamicin-collagen sponge, in reducing wound infection. Int Surg. 2014;99:565-70.

22. Page CP, Bohnen JM, Fletcher JR, McManus AT, Solomkin JS, Wittmann DH. Antimicrobial prophylaxis for surgical wounds. Guidelines for clinical care. Arch Surg. 1993;128:79-88.

23. Binnebösel M, Junge K, Kaemmer DA, Krones CJ, Titkova S, Anurov M, et al. Intraperitoneally applied gentamicin increases collagen content and mechanical stability of colon anastomosis in rats. Int $\mathrm{J}$ Colorectal Dis. 2009;24:433-40.

24. Vaneerdeweg W, Hendriks JM, Lauwers PR, leven M, Eyskens EJ. Effect of gentamicin-containing sponges on the healing of colonic anastomoses in a rat model of peritonitis. Eur J Surg. 2000;166:959-62. 